\title{
How does Technological Dependence Affect Consumer Shopping Behavior among Baby Boomers, Millennials, and Digital Natives?
}

\author{
Muhammad Syah Fibrika Ramadhan ${ }^{1}$, Nisrina Anggi Syahputri ${ }^{2}$ \\ ${ }^{1}$ Diponegoro University, Indonesia \\ ${ }^{2}$ Jenderal Sudirman University, Indonesia
}

\begin{abstract}
As the technology develop rapidly, people's life is more convenient in many aspects. For instance, technology is facilitating the way people shop. In this day and age, people does not need to go to market to buy things they want as they can get it by online shopping. This way is certainly saving the time, the money as well because they do not need to pay the transportation cost. However, with the assistances that technology offered, not all people are overly dependent on technology. Some of them, mostly baby boomers gen, tend to life the old-fashioned way. This research aims to find out the difference among three generations, including baby boomers, millennials, and digital natives in their dependence on technology and how it affects their shopping behavior including the shopping objective, shopping frequency, deciding online or offline, shopping hour as well as brand choice. This study investigated about 138 persons, consisted of $30(22 \%)$ baby boomers, $34(25 \%)$ millennials, and $74(53 \%)$ digital natives. The data were collected using the questionnaire consisted of 29 questions related to daily interaction to technology and shopping behavior. Oneway ANOVA was used to analyze the data. The result shows that among baby boomers, millennials, and digital natives have different responses of their technological dependence relating to shopping behavior. However, there is no significant difference among three generations. Each generation have different trait of shopping. Thus, the marketer should to know what kind of generation of their target in order to give the appropriate marketing.
\end{abstract}

Keywords:- Baby boomers, Digital natives, Millennials, Shopping behavior, Technological dependence.

\section{INTRODUCTION}

\section{$>$ Research Background}

Human life and technology are two things that cannot be separated since society nowadays is dependent on technology. Over decades, technology has changed the way people life in many aspects, one of them is economy field (Brynjolfsson \& Saunders 2009). According to Prasetyo (2008), the economic growth is influenced by the development of technology. Goldman Sach (2016) in Andreea Fortuna Şchiopu's study (2016) indicates that there is a generation that has a definite impact on economy in a period of globalization which is influenced by ample technological changes and economic difficulties. In the past time, technology played a role in improving the human resource quality through education and currently technology is able to determine the quality of economic growth (Mukhlis, 2009) by involving in kinds of economic activities.

One of economic activities is purchasing the goods. This study focus on how technology influences the goods purchasing. As the technology develop, the way to purchase things have changed. According to Narwal and Sachdeva (2013), technology has a great influence on consumer purchase behavior. As the online and offline world coverge, technology makes consumers expect more than ever to consume products and services any time and any place, so the marketing and sales must reach a new level (Tracy Francis and Fernanda Hoefel, 2018). There are some generations with different shopping behavior without time and place boundaries. Companies need to know and use advanced analytics to improve their insights from consumer data that can improve their strategic value and creates the new one by itself for their technology utilization.

In fact, the internet or online shopping is becoming familiar among society. Consumers worldwide are increasingly using the internet to search for information, socialise, co-creat idea and also to purchase products and services (Bargh and Mc Kenna, 2004; Samanjar Ashraf and Rodrigo Pérez-Vega, 2015). Internet shopping fulfills several consumer needs more effectively and efficiently than conventional shopping. Online shopping facilitates many things, such as the payment is becoming easier, the information provided is ample and purchased order can be booked simply. Likewise, consumers can efficiently get significant knowledge about firms, products and brands, and thereby enhance their competency in making sound decisions while shopping. Moreover, compared to conventional shopping, online shopping offers less price and creates awareness about latest products with least efforts so that comparison among products become easy.

Nevertheless, although technology has provided many facilities to do shopping, some people still prefer the conventional shopping, particularly they are who unskilled and lack of information of technology itself. In the light of the consumers' age, Wood (2002) observed that as compared to older consumers, younger adults, especially those under age 25, are more attracted in adopting new technologies, like the Internet, to find out about new products, search for product information, and compare and 
assessing alternatives. Reason behind this is that older consumers may perceive the benefits of Internet shopping to be less than the cost of investing in the skill needed to do it effectively, and therefore avoid shopping on the Internet (Ratchford, Talukdar, and Lee, 2001).

According to Parment (2013) in Petra Krbová and Tomáš Pavelek (2015), the new digital technologies (like internet, applications, social media, mobile device, etc) and its fast progress influence all generations shopping behavior, especially for millennials and digital natives generation as the industrial revolution has changed in the end of $19^{\text {th }}$ century which created new way to purchase decision and their shopping behavior.

Besides, the difference of technological dependence among distinguish generations probably affect their shopping behavior. According to Stillman and Stillman (2018), there are five generations based on the birth. Traditionalists who were born before year 1946, the baby boomers who were born from 1946 to 1964 , X generations who were born from 1965 and 1979, millennials who were born between 1980 and 1994, and at last the Z generations who were born between 1995 and current year. Andreea Fortuna Şchiopu et al (2016) claim that marketers get behind on the knowledge about the millennials profile and consumers behavior, which gives way to a number of concerns regarding permanent adaptation to consumer requirements. Consumer behavior may happen in various thoughtless situations (Lim Yi Jin et, al, 2015; Banyte and Raisyte, 2009) and in all generations who will always consider when to purchase and what impression toward the products (Lim Yi Jin, et al , 2015; Saylor.org, 2013). He, et al in Lim Yi Jin et, al, 2015 also suggested that future study should study on the actual online shopping behavior. It is important nto study about consumer behavior like how to understand what teh consumer feel, think and want form products and services.

The baby boomer generation is significant for its size in population and its distinct of social and demographic characteristics. Baby Boomers are more likely welleducated, good behavior, and more racially and ethnically diverse than their predecessors, the traditionalists. In terms of shopping behavior in modern age, although they have used modern technology, in this case smartphone for communication, most of them tend to purchasing by offline and going to the physical store (Okezone, 2017). A study by Samanjar Ashraf and Rodrigo Pérez-Vega (2015) identified that younger generations will feel that it is an easy task to learn how to use the technology to online shopping, but they assumes it's not the case for older generations like baby boomer as they might have a harder time learning how to use the technology.

Millennials, so called Generation $\mathrm{Y}$ or iGen (abbreviation of the term Internet Generation) is described as a cohort of people born between years 1980-1994 (Bednall, Valos, Adam, Mc Leod, 2012; Petra Krbová and Tomáš Pavelek, 2015). According to Luttrell and McGrath (2015) in Andreea Fortuna Şchiopu et al (2016), the term
"Millennials" has been associated with a number of tags such as Generation Y, Digital Generation, GenMe, netGeneration, The Entitled Generation, GenNext, and also Echo Boom Generation.

Different to baby boomers, the millennials generations (Y generations) is take more advantages of their smartphone to purchasing the goods. Sugianto (2018) claimed that shopping is one of the majority of millennials priority. Thus, millennials have a good buying power that force the economic power. As the shopping is an important activity, they find out the way to shopping effectively. A study by the Boston Consulting Group (2012) in Andreea Fortuna Şchiopu et al (2016) identified several inherent characteristics of Millennials. Millennials are young consumers who have confidence in their power to influence and in the recommendation from their friends. According to Benckendorff, Moscardo and Pendergast (2010) in Andreea Fortuna Şchiopu et al (2016) millennials natively digital in terms of how to use technology in a multitasking way, they show a strong personal interconnectivity. Parment (2013) in Petra Krbová and Tomáš Pavelek (2015) assumed that millennials holds a great purchase power and very able to spend their money in impulsive way, because they are the generation who in the process of becoming a parent from a child.

Digital Natives is described as a cohort of people born between years 1995-2020. The have some characteristics such as undedined ID (like expressing individual truth), "communaholic" (be radically inclusive: connecting through different truths), "dialoguer" (have fever confrontations and more dialogue: understanding different truth), "realistic" (live life pragmatically: unvelling the truth behind all things) and also they are uniqueness, unlimited and ethical generation (Tracy Francis and Fernanda Hoefel, 2018).

Regarding to digital native generations ( $\mathrm{Z}$ generations), although they are extremely digitally savvy, they do not purchase as much as millennials do. In this case for the recent time, their age is still young hence their shopping is chaperoned by their parents (Forbes 2017). The different trait toward shopping behavior among three generations should be understood by the marketer in order to generate effective market.

\section{$>$ Research Questions}

How does technological dependence affect consumer shopping behavior among baby boomers, millennials and digital natives?

\section{Research Purpose}

In the present study, we compare the technological dependence of three generations which are baby boomers, millennials, and digital natives. This research aims to find out the difference among three generations in their dependence on technology and how it affects their shopping behavior including the shopping objective, shopping frequency, deciding online or offline, shopping hour as well as brand selection. 


\section{METHOD}

\section{Participants}

The data were gathered from three generations which are baby boomers, millennials (gen Y), and digital natives (gen Z). The total number of participants for this study was 138 which the baby boomers, millennials, and digital natives are accounted for $30(22 \%), 34(25 \%)$, and $74(53 \%)$ respectively. The range of participant age of baby boomers is from 54 to 72 year, age range of millennials is from 2438 year, and age range of digital natives is from 6-23 year.

\section{Instrument}

The instrument administered to participants was the questionnaire, consisted of 29 items regarding the daily interaction to technology and shopping behavior, covering four main aspects that are the shopping objective, shopping frequency, deciding online or offline, shopping hour as well as brand selection. The participants were asked to read carefully each statements provided then they choose the answer of each statements in form Likert scale ranging 1-5 (strongly disagree to strongly agree). The example of the statement is shown in Table 1 .

\begin{tabular}{|c|c|}
\hline No & Item \\
\hline 1. & Technology is a new thing for me \\
\hline 2. & Technology is the interesting thing for me \\
\hline 3. & Technology plays an important role for my life \\
\hline 4. & I use technology everyday \\
\hline 5. & I access the internet everyday \\
\hline 6. & Technology influences the way I shop \\
\hline 7. & Technology influences my shopping purpose \\
\hline 8. & Technology influences my shopping frequency \\
\hline 9. & Technology influences my shopping time, I do not depend on time to do shopping \\
\hline 10. & Technology influences the brand choices that I want to purchase \\
\hline
\end{tabular}

Table 1:- The example of item of the instrument

\section{$>$ Data analysis}

To analyze the data, the one-way ANOVA is performed to investigate if there is the difference the influence of technological dependence toward shopping behavior among three generations (baby boomers, millennials, and digital natives). The further analysis was described the responses of participants to each statements of the instrument.

\section{FINDING}

One-way ANOVA is run to find out the interaction effect among different generations on technological dependence towards shopping behavior. Based on ANOVA test, we found there is no significant difference of technological dependence towards consumer shopping behavior among three generations because the $p=0.396$ (significance if $\mathrm{p}<0.05$ ) as depicted in the Fig. 1 .

\section{ANOVA}

AVERAGE
\begin{tabular}{|l|r|r|r|r|r|}
\hline & \multicolumn{1}{c|}{$\begin{array}{c}\text { Sum of } \\
\text { Squares }\end{array}$} & \multicolumn{1}{c|}{ df } & Mean Square & F & Siq. \\
\hline Between Groups & .859 & 2 & .429 & .933 & .396 \\
Within Groups & 62.113 & 135 & .460 & & \\
Total & 62.972 & 137 & & & \\
\hline
\end{tabular}

Fig 1:- The result of one-way ANOVA test

Regards to the response of participants to the item of questionnaire, the Table 2 is shown. In terms of participants' knowledge about the technology, most of the digital native generations claimed that technology is not the new thing for them thus they know the technology very well. As opposed to the digital natives, more than $50 \%$ claimed that they have just known the technology. In the other side, $50 \%$ of millennials agree that technology is new thing and the rest of them disagree. Regarding the interaction with technology, less or more $90 \%$ of person in each generation stated that they often use technology in their daily life.
As an overall trend, Table 2 illustrates that the technological dependence affects the people shopping behavior among three generations. The mean of people who agree with the statements is more than $70 \%$ with the most is digital natives and the least is baby boomer generation. The statement of technology has influenced the way people do shopping is approved by $77 \%$ of baby boomers, $79 \%$ of millennials, and $86 \%$ of digital natives. Interestingly, $80 \%$ of baby boomers claimed that technology has affected their shopping purpose. This amount is more than the millennials, yet still less than digital natives. With regards to technology affects the shopping frequency, the majority of all three generations agree with that. However, the amount of percentage of people who agree is not showing the 
significant difference. Additionally, most of them also agree that the technology has affected their shopping hour which millennials show the highest percentage, accounted for $79 \%$. In case the technology has influenced people in brand choice, baby boomers showed the lowest percentage that is only $60 \%$ meanwhile the millennials and digital natives are slightly higher that are $71 \%$ and $77 \%$ respectively.

\begin{tabular}{|c|c|c|c|c|c|c|}
\hline \multirow{2}{*}{ Item } & \multicolumn{2}{|c|}{ Baby Boomers } & \multicolumn{2}{c|}{ Millennials } & \multicolumn{2}{c|}{ Digital Natives } \\
\cline { 2 - 7 } & $\begin{array}{c}\text { Disagree } \\
(\mathbf{\%})\end{array}$ & $\begin{array}{c}\text { Agree } \\
(\boldsymbol{\%})\end{array}$ & $\begin{array}{c}\text { Disagree } \\
(\mathbf{\%})\end{array}$ & $\begin{array}{c}\text { Agree } \\
(\boldsymbol{\%})\end{array}$ & $\begin{array}{c}\text { Disagree } \\
(\mathbf{\%})\end{array}$ & $\begin{array}{c}\text { Agree } \\
(\boldsymbol{\%})\end{array}$ \\
\hline A & 33 & 67 & 50 & 50 & 59 & 41 \\
\hline B & 10 & 90 & 9 & 91 & 3 & 97 \\
\hline C & 23 & 77 & 21 & 79 & 14 & 86 \\
\hline D & 20 & 80 & 29 & 71 & 14 & 86 \\
\hline E & 30 & 70 & 29 & 71 & 27 & 73 \\
\hline F & 23 & 77 & 21 & 79 & 22 & 78 \\
\hline G & 40 & 60 & 29 & 71 & 23 & 77 \\
\hline
\end{tabular}

Table 2:- The percentage of participants' responses to item

N.B. Item A refers to the participants' knowledge about the technology, item B refers to the participants' daily interaction with the technology, item $\mathrm{C}-\mathrm{G}$ refers to the technology impact to shopping behavior.

\section{DISCUSSION}

Most of baby boomer generation claimed that technology is the new and modern thing for them. However, some of them has known the technology well due to the technology has entered to their daily life. Conversely, for those who are digital native generation ( $\mathrm{Z}$ generation), technology is kind of primary necessity for life. It is shown in the result which they mostly disagree that technology is a recent thing. Ali (2016) said that millennials and digital natives gen consider the technology as their daily life. This is aligned with Stillman and Stillman (2018) that stated the $\mathrm{Z}$ generation has integrated with the technology. Furthermore, technology is an extension of the brain of $\mathrm{Z}$ generation. This result is confirmed by a study by Tracy Francis and Fernanda Hoefel (2018) which indicate that digital natives know how to access information and develop a point of view quickly and also they are mostly well educated about technology and brands and the realities behind them.

Regarding the interaction with the technology, about 90\% people of each generation claimed that they use technology every day. The interaction in this case is frequency of people in using technology, accessing an internet, communicating by online, and seeing the online advertisement in daily life. Buru (2015) Andreea Fortuna Şchiopu et al (2016) indicates that millennials represent an active audience that wants collect and share their consumption experiences with family and friends through their online media. They want to share inspiration for other people. Teknopreneur (2018) suggested that the most of technology users is digital native generation while the least is the baby boomers. In the present study, the amount of baby boomers who interact with technology in their daily life is quite high. Due to the research is conducted in the city, this variable may affect its result. In the city, the children tend to teach their parents about technology, thus, the older people has been technologically literated.

Yasav (2016) stated that technology brings the impact to shopping style. This is similar with the result of this study. Petra Krbová and Tomáš Pavelek (2015) also assumed that millennial individuals consider the quality of information as the most important when choosing an online shop. It means we can suppose that they spend much more time by searching and analyzing information like the details of products and services before they decide to online shopping and choose an online shop. The intensive interaction with technology may affect the people mindset, hence, what people see and get from their interaction with the technology is also possible to change their mindset to shopping. While some of baby boomers is still depend on the offline shopping, the millennials and digital native generation consider the ease they give when doing online shopping. Some of them think that the goods offered in online shopping is cheaper than what in available in physical store. Also, online shopping is easier to do than the offline shopping since online shopping does not require them to go the shop. They also believe that shopping in physical store is safer and trusted as there are many frauds in online shopping. Therefore, although the good features and simple way to shopping has offered by online shopping, they keep prefer to do offline shopping.

According to Narwal (2013), shopping that is done with using IT has many purposes. In terms of the shopping purpose, the technology has not significant effect on this. Most people among three generations is still considered between the necessity and the wish. More than $50 \%$ of them will purchase the goods if they really need its goods. Nevertheless, it is about $27 \%$ people in the recent study claimed that they buy everything that is in social media trending. This phenomenon showed that some of people is keeping up to date on the recent trending and trying to 
follow the trending since they want to be admitted of their presence in social media. The social media trending that influence them is not only fashion, but also the foods and drinks.

In terms of the frequency of shopping, the technology is not impact more. Although most of three generations claimed that technology influences their shopping frequency, the number of frequency is less than 3 times in a week. Of 138 participants, there are only $23 \%$ people who shop three times per week. Besides, in the research of Yasav (2016), the using of technology has increase the frequency of shopping as accounted for 53\%. This can be related to the consumptive life style of each person that might be different.

The technology breaks the limit of hour shopping. By using technology, people can shop beyond the work hour of physical store. Thus, more than $77 \%$ participant came from three generations agree with this. This is aligned with Katawetawaraks (2011) that stated the reason people choose to online shopping is because the consumer can shop everything without worrying the place and time, indicating they can do online shopping everywhere and everytime as they want to do. $60 \%$ of participants in this study stated that their shopping hour is changed due to the technology and $80 \%$ of them claimed that by utilizing the technology, they do not spend much time for shopping. Generally speaking, the online shopping is the effective method of shopping since it is not requiring more time.

In case of brand choice, the technology has good control among all three generations, particularly the digital native generations. It is similar with the study of Mahmud (2017) that the development and using of technology has change the one's paradigm in choosing the brand they want to purchase. Typically, they tend to buy the things that is advertised in online advertisement (e.g. website and social media). Furthermore, in social media such as Instagram the marketer using the famous artist to advertise the products that usually become the trending topic. Thus, people prone to choose the brand of products by the following the trend in social media. Although technology has effected the shopping behavior of three generations in this study, the difference effect among three generations is not significant. As mentioned above, this is probably due to the technology literation has been widely known to various generations.

\section{CONCLUSION}

To conclude, each generation that is investigated in this research (baby boomers, millennials, and digital natives) have the different shopping behavior including the shopping objective, shopping frequency, deciding online or offline, shopping hour and brand choice. The presence of technology and how high they depend on its technology are the reason of the difference.

\section{REFERENCES}

[1]. Ali, Hasanuddin, and Lilik Purwandi. (2016). Indonesia 2020: The Urban Middle-class Millenials. Alvara Research Center.

[2]. Ashraf, Samanjar and Rodrigo Pérez-Vega. (2015). Insight into Dubai's Generation Y Online Shopping Behavior: Exploring the Limitations of the Technology Acceptance Model with the Digital Natives. International Conference on Organization an Management. Dubai : Heriot-Watt University. 1-25.

[3]. Brynjolfsson, Erik, and Adam Saunders. (2009) Wired for innovation: how information technology is reshaping the economy. MIT Press.

[4]. Forbes. (2017). 5 Differences Between Marketing to Millennials Vs Gen Z https://www.forbes.com/sites/deeppatel/2017/11/27/5differences-between-marketing-to-millennials-vs-genz/ (accessed October 13, 2018).

[5]. Francis, Tracy and Fernanda Hoefel. (2018). True Gen: Generation $Z$ and Its Implications for Companies. Brazil: McKinsey \& Company.7-9.

[6]. Katawetawaraks, Chayapa, and Cheng Lu Wang. (2013). Online shopper behavior: Influences of online shopping decision.

[7]. Krbová, Petra and Tomáš Pavelek. (2015). Generation Y: Online Shopping Behavior of The Secondary School and University Students.

[8]. Mahmud, Md. S. (2017). Factor's affecting costumer's brand choice: A literature survey. International Journal of Multidisciplinary Research and Development. 300-304.

[9]. Mukhlis, Imam. (2009). Eksternalitas, Pertumbuhan Ekonomi dan Pembangunan Berkelanjutan dalam Perspektif Teoritis. Jurnal Ekonomi Bisnis.

[10]. Narwal, Mahabir, and Geeta Sachdeva. (2013). Impact of information technology (IT) on consumer purchase behavior. Researchers World. 41.

[11]. Okezone. (2017). Kenali Perbedaan Generasi X, Y, dan $Z$ dalam Berbelanja. https://economy.okezone.com/read/2017/01/27/320/16 02838/kenali-perbedaan-generasi-X-y-dan-Z-dalamberbelanja (accesed October 13, 2018).

[12]. Prasetyo, P. Eko. (2008). The Quality of Growth: Peran Teknologi dan Investasi Human Capital Sebagai Pemacu Pertumbuhan Ekonomi Berkualitas. JEJAK: Jurnal Ekonomi dan Kebijakan.

[13]. Pruchno, Rachel. (2012). Not your mother's old age: Baby Boomers at age 65. 149-152.

[14]. Ratchford, Brian T., Debabrata Talukdar, and MyungSoo Lee. (2001). A model of consumer choice of the Internet as an information source. International Journal of Electronic Commerce 5. 7-21.

[15]. Şchiopu, Andreea Fortuna, et al. (2016). The Influence of New Technologies on Tourism Consumption Behavior of the Milolennials. Amfiteatru Economic Journal. Romania: Bucharest University of Economic Studies, 831-832. 
[16]. Stillman, D., \& Stillman, J. (2018). Generasi Z, Memahami Karakter Generasi Baru yang Akan Mengubah Dunia Kerja. Jakarta : PT. Gramedia Pustaka Utama.

[17]. Sugianto, Raphael Vivaldo. (2018). Pengaruh SelfCongruity, Curiosity, dan Shopping Well-Being Terhadap Pola Konsumsi Fast Fashion pada Generasi Millennial di Surabaya. Agora.

[18]. Teknopreneur. (2018). Penetrasi Internet Indonesia di dominasi Gen $Z$. http://teknopreneur.com/2018/02/19/penetrasiinternet-indonesia-didominasi-gen-z/ (accesed Ocotober13, 2018).

[19]. Wood, Stacy L. (2002). Future fantasies: a social change perspective of retailing in the $21 \mathrm{st}$ century $s$. Journal of retailing.77-83.

[20]. Yasav, Sue. (2015). The impact of digital technology on consumer purchase behavior. 